\title{
Complex interactions in microbial food webs: Stoichiometric and functional approaches
}

\author{
Presentación Carrillo ${ }^{1}$, Juan Manuel Medina-Sánchez², Manuel Villar-Argaiz², \\ José Antonio Delgado-Molina² and Francisco José Bullejos ${ }^{2}$ \\ ${ }^{1}$ Instituto del Agua, Universidad de Granada. 18071 Granada, SPAIN \\ 1,2 Departamento de Ecología, Facultad de Ciencias, Universidad de Granada, 18071 Granada, SPAIN \\ Corresponding author:pcl@ugr.es
}

\begin{abstract}
The food web structure in some high mountain lakes deviates from the established tendency of high heterotrophic bacteria: phytoplankton biomass ratios in oligotrophic ecosystems. Thus, the microbial food web in La Caldera Lake is weakly developed, and bacteria constitute a minor component of the plankton community in terms of abundance, biomass and production. Autotrophic picoplankton is absent, and heterotrophic microbial food web is weakly developed compared to a grazing chain dominated by calanoid copepods and a phytoplankton community mainly composed of mixotrophic flagellates. In order to explain the singular food web structure of this lake, functional, stoichiometric and taxonomical approaches are followed to assess, on various temporal and spatial scales, the relevance of stressful abiotic factors (ultraviolet solar radiation and P-limitation) on the structure and functioning of this ecosystem. P-availability was the main factor controlling the algal biomass whereas bacterial P- limitation was a transient phenomenon. The algae-bacteria relationship was predominately commensalistic. In contrast to algae, full-sunlight radiation had no negative effect on bacterial growth but rather enhanced bacterial dependence on the carbon released by algae. The prevalence of the commensalistic-mutualistic relationship and the development of a more complex microbial food web were related to the stoichiometry of algae and bacteria (N:P ratios). The microbial food web only developed at balanced algal and bacterial N:P ratios, with the appearance of ciliates after a nutrient pulse. However, mixotrophic algae dominated the planktonic community under P-deficit conditions, and they were the main factor controlling bacterioplankton. Their regulatory effect has a dual nature: (i) a resource-based control, where bacteria depend on the photosynthetic carbon released by algae, i.e., a commensalistic interaction ("without you I cannot live"); and (ii) a predatory control, where bacteria is a prey for mixotrophs ("with you I die"). Hence, the niche of microheterotrophs (nanoflagellates and ciliates) is occupied by mixotrophs, and there is a resulting simplification of the planktonic structure. With respect to the carbon cycle, mixotrophic bacterivory constitutes a "by-pass" for the flux of $\mathrm{C}$ towards the grazing chain, precluding the development of a complex heterotrophic microbial food web. Mixotrophs thereby improve the energetic transfer efficiency in high mountain lakes through a reduction in the number of trophic levels. Antagonistic effects of UVR x P interactions on the algae-bacteria relationship were caused by an enhancement of dual (resource and predation) control. Based on these results, an alternative model for the flux of $\mathrm{C}$ in autotrophic high mountain lakes has been proposed.
\end{abstract}

Key words: Carbon flux, high mountain lakes, microbial loop, nutrient limitation, stoichiometry, ultraviolet radiation.

\section{RESUMEN}

La estructura de la red trófica en algunos lagos de alta montaña, se aleja de los patrones establecidos para ecosistemas oligotróficos que proponen el predominio de la red trófica microbiana sobre la cadena de pastoreo. Así, en la laguna de La Caldera las bacterias son el componente minoritario de la comunidad planctónica en términos de abundancia, biomasa y producción. El picoplancton autótrofo está ausente y la red microbiana heterotrófica se encuentra escasamente desarrollada frente a una cadena de pastoreo dominada por copépodos calanoides y algas mixotróficas. Para comprender los mecanismos que determinan esta estructura trófica hemos seguido diferentes aproximaciones de análisis: funcional, estequiométrica y taxonómica sobre distintas escalas espaciales y temporales, en relación con los principales factores de estrés abiótico (radiación ultravioleta y limitación por fósforo) que controlan el funcionamiento de los ecosistemas de alta montaña. Nuestros resultados indican que la disponibilidad de fósforo, de forma generalizada, controla la biomasa algal y de manera transitoria la bacteriana, estableciéndose entre ambas comunidades una relación comensalista. La radiación solar completa no afecta negativamente el desarrollo de las bacterias y si el de las algas y potencia la relación de dependencia por el carbono orgánico (comensalismo) entre algas y bacterias. El predominio de la relación comensalista-mutualista y el desarrollo del bucle microbiano esta relacionado con la estequiometría (razón N:P) de algas y bacterias. Así, sólo cuando la razón N:P de algas y bacterias es equilibrada para crecer, un pulso de 
nutrientes permite el desarrollo del bucle microbiano. En condiciones naturales de déficit de P, sin embargo, existe un predominio de "algas" con metabolismo mixotrófico. Las algas mixotróficas ejercen un efecto regulador dual sobre las bacterias que denominamos Ni contigo ni sin ti, (i) control por depredación, donde las bacterias son consumidas por algas mixotróficas ("contigo me muero"), (ii) control basado en los recursos estableciéndose una relación de dependencia de las bacterias sobre del carbono liberado por las algas ("sin ti no puedo vivir"). La mixotrofia supone un simplificación en la cadena trófica microbiana, donde los mixótrofos ocupan el nicho potencial de nanoflagelados y ciliados. Desde un punto de vista energético implica un cortocircuito en el flujo de energía y un incremento en la eficiencia de transferencia energética en ecosistemas ultraoligotróficos y con alta dosis de radiación ultravioleta $(R U V)$. Los efectos de la interacción entre RUV y pulsos de P tienen un efecto antagónico sobre la interacción alga-bacteria, intensificando la interacción comensal-depredadora. A partir de los resultados obtenidos proponemos un modelo alternativo de flujo de energía para ecosistemas autotróficos de alta montaña.

Palabras clave: Bucle microbiano, Estequiometría, Flujo del carbono, Limitación por Nutrientes, Lagos de Alta Montaña, Radiación Ultravioleta

\section{INTRODUCTION}

The food web constitutes one of the most complex conceptual phenomena in modern Biology (Pimm et al., 1991). This complexity is increased by the "nodes" of the food web, through which energy and materials flow, are formed by individual organisms of diverse species, each individual is a complex biochemical system, and every species is the product of ongoing evolutionary change (Holt, 1995). Nevertheless, according to Margalef, knowledge of the relations among elements is more important to the understanding of a system than knowledge of the precise nature of its constituents (Margalef, 1992). It is therefore crucial to study the interactions that take place in the food web -an important issue in the emerging science of "Biocomplexity" (Michener et al., 2001)-, and to develop appropriate concepts or key variables for this purpose. Trophic level (tropho-dynamic view, Lindeman, 1942) and body size, which control many of the physiological properties of organisms and influence the trophic structure of the communities (Rodriguez, 1999), are among two of the traditionally considered variables. Recently, Sterner \& Elser (2002) proposed stoichiometry as a tool for ecological analysis in order to relate the elemental composition of organisms (carbon $[\mathrm{C}]$, nitrogen $[\mathrm{N}]$ and phosphorus $[\mathrm{P}]$ ) to their growth rates and resource availability (Biological stoichiometry; Elser et al., 1996). Furthermore, stoichiometry permits the examination of the balance of energy (usually characterized in carbon terms) with multiple chemical elements (e.g., nitrogen and phosphorus) in the organisms, and of the relationship between ecological interactions and biogeochemical cycles (Ecological stoichiometry; Sterner \& Elser, 2002). More recent studies of food webs suggest that the supposed complexity of the food web is more apparent than real (Elser \& Hessen, 2005). On the grounds of biosimplicity, they proposed the consideration of the Darwinian paradigm in food web models alongside elemental composition and the laws of thermodynamics. This multiple approach avoids the bias implied by the use of a single tool to study the complexity of food webs. As these authors put it, "If your only tool is a hammer, then every problem looks like a nail". This multiple approach has been adopted in the food web analysis presented in this review.

\section{WHAT WE KNOW AND WHAT WE DO NOT UNDERSTAND}

Food webs in aquatic ecosystems function via the channeling of energy and the flux of materials among diverse organism assemblages organized in two chains: the classical grazing chain (phytoplankton-zooplankton-fish), traditionally considered the main pathway for the flow of energy within these ecosystems; and the so-called "microbial loop", (bacteria-heterotrophic nanoflagellates [HNF] - ciliates). The latter is parallel to and converges with the grazing chain via zooplankton consumption of bacteria, HNF, and ciliates (Pomeroy, 1974; Azam et al., 1983). The clearly established 


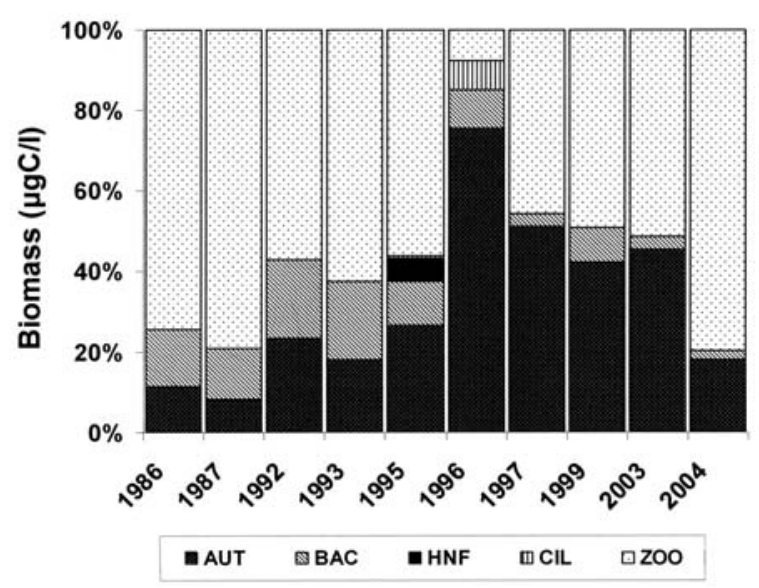

Figure 1. Inter-annual variability of the food web structure of the plankton community in La Caldera Lake. AUT, phytoplankton; BAC, bacteria; HNF, heterotrophic nano-flagellates; CIL, ciliates; ZOO, zooplankton. Variabilidad interanual de la estructura de la red trófica de la comunidad planctónica de la laguna de La Caldera. AUT, fitoplancton; BAC, bacteria; HNF, nanoflagelados heterotróficos; CIL, ciliados; ZOO, zooplancton.

dominance of the microbial communities in oligotrophic ecosystems (del Giorgio \& Gasol, 1995; Gasol et al., 1997; Vadstein, 2000) derives from their ability to consume organic matter and mineral nutrients at higher rates compared to algae (Biddanda et al., 2001). The dominance of the microbial community in the metabolic balance of oligotrophic ecosystems invites an in-depth study of: the functioning of this compartment, the effects of variations in abiotic factors (i.e. ultraviolet radiation [UVR], nutrient availability) on interactions among its components, and the propagation or attenuation of stress-factor effects throughout the food web. The biological simplicity of the high mountain lakes in Sierra Nevada National Park, which is mediated by strong physical regulation and extreme oligotrophic conditions, makes them an ideal setting for observing and modelling the structure and functioning of the microbial food web. Thus, on an inter-annual scale, the food web structure of one of these ecosystems, La Caldera Lake (Fig. 1), deviates from the trends established for oligotrophic ecosystems, with scant microbial loop development, frequently represented only by bacteria. The first question that arises is then,

\section{¿Why does the microbial loop fail to develop in La Caldera Lake?}

Algae-bacteria interactions have been shown to be the key link between the classical grazing chain and the microbial food web, and the coexistence of both trophic levels is a "sine qua non" condition for the persistence of the ecosystem (Daufresne \& Loreau, 2001). Different analyses in freshwater and marine ecosystems of the relationship between the biomass/production of bacteria and algae (Cole et al., 1988; Teira et al., 2001; Carrillo et al., 2002) have shown a direct relationship between these organisms. The commensalistic algae-bacteria relationship based on bacterial dependence on organic $\mathrm{C}$ released by algae has provided the key explanation of some empirical trends. Accordingly, it is assumed that bacterioplankton is not limited by mineral nutrients (Chrzanowski \& Grover, 2001) and establishes an indirect mutualistic interaction with algae, whereby algae provide carbon to sustain bacterial growth and bacteria recycle mineral nutrients to support algal growth (Aota \& Nahajima, 2001). This mutualistic interaction is often established in lakes with negligible allochthonous $\mathrm{C}$ input, absence of anoxic (or hypoxic) hypolimnion (see discussion in Pace \& Cole, 1994), or a high N:P inorganic ratio (Lee et al., 1994), all characteristics of high mountain lakes. Nevertheless, preliminary studies in La Caldera Lake showed a decoupling between the two communities (Reche et al., 1996). Since the algae-bacteria relationship is critical to an understanding of microbial loop development, deeper analysis of the nature of this interaction is required.

Daufresne \& Loreau (2001) were the first to propose that the alga-bacteria relationship varies according to stoichiometry of $\mathrm{C}$ and nutrient content in the matter transferred from primary producers to decomposers. Because the composition of the released organic matter and the nutritional status of the algae are intrinsically linked (Obernosterer \& Herndl, 1997; Caron et al., 2000; Sterner \& Elser, 2002), organism stoichiometry may be a useful 
tool to understand algae-bacteria interactions, since it yields data on nutrient demands and nutrient limitations to growth. Thus, according to the elemental $\mathrm{C}: \mathrm{N}: \mathrm{P}$ cell content and the availability of substrates, bacteria or algae will be limited by one element or another. For example, if algae are P-deficient (high $\mathrm{C}: \mathrm{P}$ ), the organic matter released will be characterized by a high $\mathrm{C}: \mathrm{P}$ ratio, leading towards a $\mathrm{P}$ limitation for bacteria. The higher nutrient requirements of bacteria in terms of biomass, $\mathrm{C}: \mathrm{P}$ and $\mathrm{N}: \mathrm{P}$ ratios are met by the immobilization of mineral nutrients (Daufresne \& Loreau, 2001). Therefore, competition results from a high $\mathrm{C}$ :nutrient ratio of the matter transferred between algae and bacteria. Thus, the algae-bacteria relationship can be changed from mutualism to competition for mineral nutrients, especially in oligotrophic environments (Aota \& Nahajima, 2001; Cotner \& Biddanda, 2002; Joint et al., 2002). Because of the dynamic nature of the algae-bacteria interaction, the relative importance of mutualism versus competition must be studied, as well as the individual and interactive effects of stressfactors (UVR and P-limitation) on this interaction. These fundamental ecological questions will be addressed in this review, allowing us to propose an alternative model for the microbial food web in high mountain lakes.

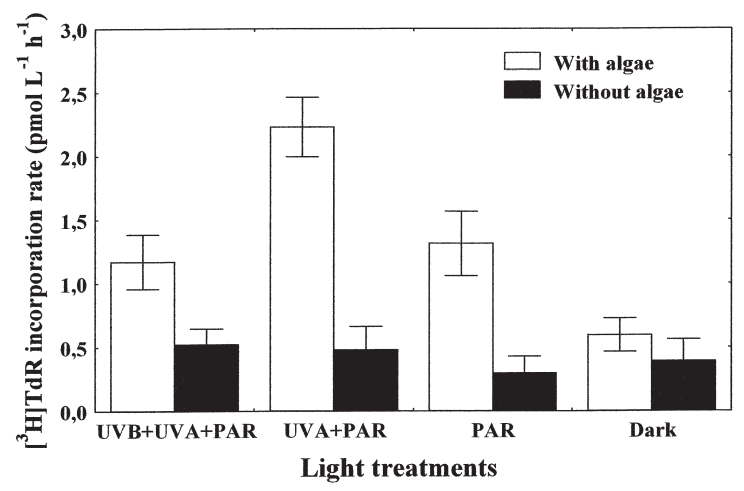

Figure 2. Bacterial $\left[{ }^{3} \mathrm{H}\right] \mathrm{TdR}$ incorporation rates in the presence versus the absence of algae under different light treatments. Error bars indicate means $\pm \mathrm{SD}, \mathrm{n}=3$. Valores de la tasa de incorporación de $\left[{ }^{3} H\right]$ TdR por bacterias en presencia vs. ausencia de algas bajo diferentes tratamientos de luz (UVB+UVA+PAR, UVA+PAR, PAR, Oscuridad). Las barras indican medias $\pm S D, n=3$.

\section{THE MICROBIAL LOOP DOES NOT DEVELOP. DAZZLED BY THE LIGHT?}

The high mountain lakes at Sierra Nevada receive a high ultraviolet radiation (UVR) flow due to their altitude $(3000 \mathrm{~m})$ and proximity to the subtropics. On the other hand, the low DOC concentration in the water of these lakes (Reche et al., 2001), a consequence of the scarce development of terrestrial vegetation in their catchment areas, allows for a high level of UVR penetration into the water column. Therefore, the low development of the microbial loop might be related to the direct negative effects of ultraviolet-B radiation $(<320 \mathrm{~nm})$ (UVB) on these communities. Experimental evaluation of the bacterial activity under different light qualities confirmed our initial hypothesis. Thus, UVB reduced bacterial $\left[{ }^{3} \mathrm{H}\right]$ TdR incorporation rates by $39-87 \%$ at the surface, although it had no significant effect at intermediate layers (Fig. 2) (Carrillo et al., 2002; Medina-Sánchez et al., 2002). In contrast, either UVA and photosynthetic active radiation (UVA + PAR) or PAR alone exerted a stimulatory effect on $\left[{ }^{3} \mathrm{H}\right] \mathrm{TdR}$ incorporation rates (Fig. 2). This bacterial response was interpreted as the result of photorepair mechanisms (Kim \& Sancar, 1993; Vincent \& Roy, 1993), which were especially efficient under high light intensities (Carrillo et al., 2002). This photorepair effect is translated into a net stimulatory full-sunlight effect (UVB + UVA + PAR) on bacterial growth (Fig. 2). Nevertheless, an adequate supply of photosynthetic carbon from algae is required to support a net increase in bacterial growth after the recovery of UVB-damaged bacteria. In fact, in experiments made in the absence of algae, this potential recovery did not manifest as enhanced bacterial growth (Fig. 2) (Medina-Sánchez et al., 2002).

Can photosynthetic $\mathrm{C}$ supply be inhibited by ultraviolet radiation? Our experimental results showed that UVR inhibits primary production (PP) but increases excretion of organic carbon by algae (EOC) (Carrillo et al., 2002). A higher proportion of this released $\mathrm{C}$ is assimilated by bacteria (\% PEA) under UVA + PAR or PAR rather than under UVB radiation. These data are compatible with the mechanism proposed 

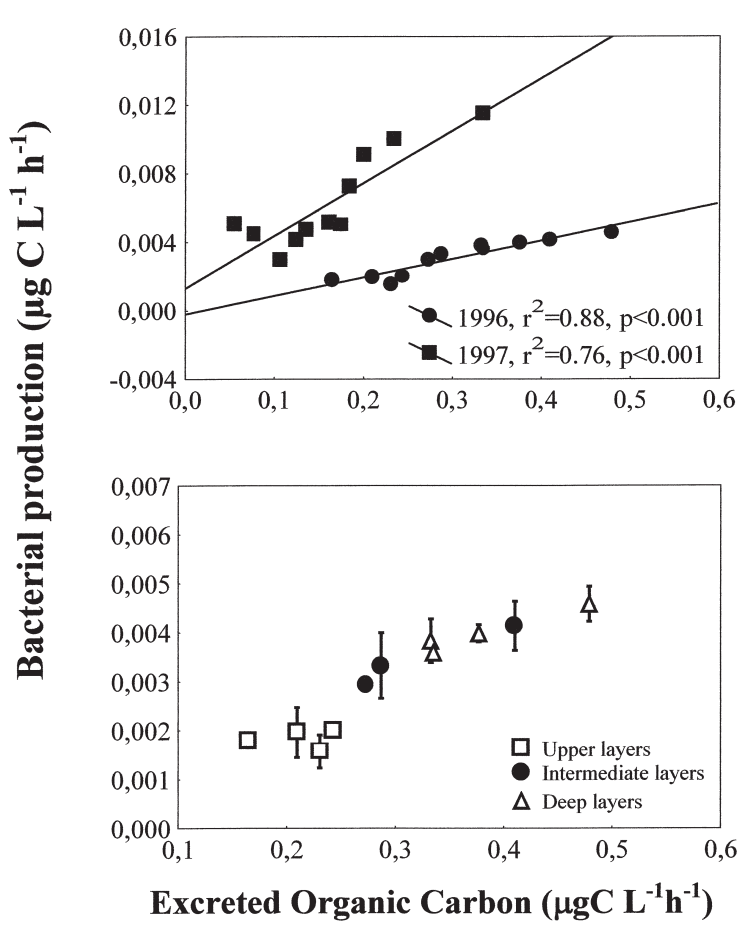

Figure 3. Annual relationship between Bacterial Production and Excretion of Organic Carbon (EOC) for the entire water column (A), and discriminating between depths in 1997 (B). Error bars indicate means \pm SD of bacterial production, $\mathrm{n}=3$. Relación anual entre Producción Bacteriana y Excreción de Carbono Orgánico (EOC) en la columna de agua completa (A) y discriminando entre profundidades (B). Las barras indican medias $\pm S D$ de producción bacteriana, $n=3$.

by Berman-Frank \& Dubinsky (1999) for the regulation of algae-bacteria interaction in poormineral nutrient ecosystems with high UVR flow, and also with the stimulatory effect on bacterial $\left[{ }^{3} \mathrm{H}\right] \mathrm{TdR}$ incorporation rates under photorepair light (UVA and/or PAR). The consistency of the results obtained (increased net bacterial activity) using two different methodological approaches suggests a relationship between the consumption of bacterial $\mathrm{C}$ and the ability to channel it to new bacterial biomass. For this reason, our group proposed the PB: PEA ratio (as percentage; $\%$ CUEb) to quantify the use of photosynthetic carbon by bacteria. Interestingly, UVA + PAR or PAR were shown to increase carbon use efficiency (Carrillo et al., 2002). Therefore, a net increase of bacterial production (PB) under high full-sunlight inten- sity is possible because the negative effect of UVB radiation on bacteria is counteracted by the positive effect of UVA and PAR (Kim \& Sancar, 1993; Kaiser et al., 1997; Davidson \& Van der Heijden, 2000), and the presence of higher photosynthetic $\mathrm{C}$ availability. A net positive bacterial response to full-sunlight would lead to a coupling between PB and PP (and EOC) (Fig. 3). In fact, when PB measurements were obtained under full-sunlight instead of the usual darkness incubations (Fig. 4), a coupled algae-bacteria relationship was verified. From all of the data above, we conclude that full-sunlight has no negative effect on bacterial development (basis of microbial loop) and increases bacterial dependence on organic carbon released by algae (commensalism). Moreover, the absence of the algal fraction produced a highly significant decrease in PB under different regions of the spectral solar radiation, confirming the dependence of bacteria on carbon released by algae ("without you I cannot live") (Fig. 2). Further questions arose from these results: (i) What other factors, besides light quality, restrict bacterioplankton and microbial loop development in La Caldera Lake?; (ii) How prevalent is commensalism versus competition between algae and bacteria during the ice-free period? A more detailed analysis of the results obtained in this ecosystem revealed that (i) the stimulation of bacterial growth under full-sunlight only occurred when bacterial elemental composition was balanced and therefore suitable for growth $(\mathrm{N}: \mathrm{P} \leqslant 20-24$ sensu Chrzanowski et al., 1996) (MedinaSánchez et al., 2002) and (ii) algae can regulate C-release depending on their elemental composition and the nutrient-availability in lake water (Berman-Frank \& Dubinsky, 1999; Vi1lar-Argaiz et al., 2002a). This ability permits algae to modify the strength of their commensalistic relationship with bacteria and can even lead to a competitive interaction (Reche et al., 1997; Villar-Argaiz et al., 2002a). These results indicate that mineral nutrient availability and algal and bacterial elemental composition can generate important constraints in the development of the microbial loop. 


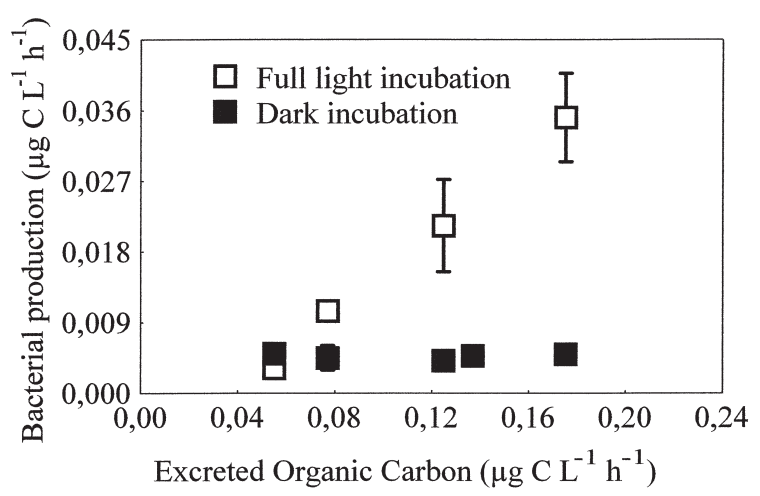

Figure 4. Relationship between Bacterial Production and Excretion of Organic Carbon (EOC) measured at upper depths in 1997, with the bacterial production data obtained under full sunlight or dark incubations. Bars indicate means \pm SD of $\mathrm{EOC}, \mathrm{n}=3$. Relación entre Producción Bacteriana y Carbono Orgánico Excretado (EOC) en la capas superficiales del lago en 1997, con medidas de producción bacteriana obtenidas en incubaciones con luz completa y oscuridad. Las barras indican medias $\pm S D$ de EOC, $n=3$.

\section{THE MICROBIAL LOOP DOES NOT DEVELOP. IS IT NUTRIENT LIMITED?}

Most high mountain lakes in Sierra Nevada are chronically P-deficient ecosystems (DIN:TP> 40; Carrillo et al., 1996; Morales-Baquero et al., 1999). This strong limitation may be the cause of the low bacterial and microbial loop development. Nevertheless, our studies have shown that variances in bacterial activity or biomass in La Caldera Lake are not explained by the concentrations of Total Phosphorus (PT) or Total Dissolved Phosphorus (TDP) (Reche et al., 1997; Medina-Sánchez et al., 1999; Carrillo et al., 2002). Moreover, P-rich atmospheric inputs (Saharan dust) (Carrillo et al., 1990a; Villar-Argaiz et al., 2001, 2002a; PulidoVillena, 2004) are largely (60-80 \%) incorporated into the algal fraction (Fig. 5) (Villar-Argaiz et al., 2001; Villar-Argaiz et al., 2002b). This preferential algal P-consumption has been demonstrated in natural observations (Fig. 5) and after experimental nutrient amendments in the short-term (hours) (Villar-Argaiz et al., 2002a; Medina-Sánchez et al., 2002), mediumterm (days), and long-term (weeks-months). These results are consistent with the greater abi- lity of algae versus bacteria to incorporate limiting nutrients at high P-substrate concentrations (Tarapchak \& Moll, 1990). These mechanisms undoubtedly offer an ecological advantage for algae since they can grow by consuming intermittent P-pulses associated with allochthonous inputs (Cotner \& Wetzel, 1992; Duarte et al., 2000) and P recycled by zooplankton (Carrillo et al., 1995, 1996; Reche et al., 1997). This generalized response to enrichment suggests that P-availability controls algal biomass in $\mathrm{La}$ Caldera Lake but is not a leading factor in the restriction of bacterial activity or biomass on a seasonal or experimental scale.

The stimulatory effect of $\mathrm{P}$ on primary producers, in some conditions, is propagated throughout the microbial loop, allowing ciliate development. C-flux quantification allowed us to propose that the complex microbial loop is established by atmospheric nutrient inputs (MedinaSánchez et al., 1999; Villar-Argaiz et al., 2002a) or P-addition, which stimulate algal growth, and algae-released organic carbon (Medina-Sánchez et al., 2006). The increase in C-availability enhances bacterial production (without changes in bacterial abundance or biomass), enabling ciliate development (Medina-Sánchez et al.,

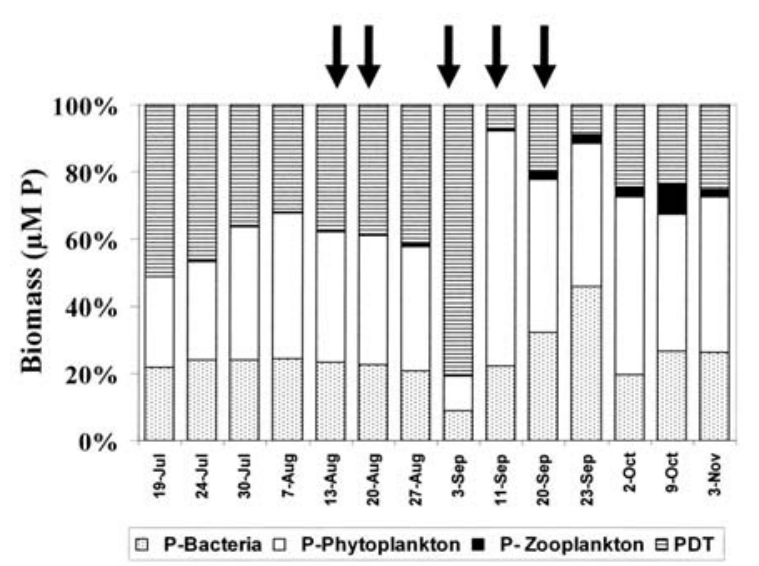

Figure. 5. Temporal distribution of phosphorus in particulate (bacteria, phytoplankton, and zooplankton) and dissolved (TDP) fractions during 1996 in La Caldera Lake. Arrows indicate humid P inputs in the Lake area. Distribución temporal de fósforo en las fracciones particuladas (bacteria, fitoplancton y zooplancton) y disuelta (TDP) durante el año 1996 en la laguna de La Caldera. Las flechas indican entradas atmosféricas húmedas de fósforo en el área de la laguna. 
1999; Villar-Argaiz et al., 2002a). These results confirm that nutrient enrichment can lead to a lengthening of the microbial food chain (Samuelson et al., 2002; Vaqué et al., 2003). Therefore, the scarce microbial loop development can at least be partly ascribed to the severe oligotrophic conditions of this ecosystem. Nevertheless, propagation of the P-pulse effect to ciliate development does not always take place in the system, raising the question as to what constrains the development of a complex microbial loop. Microcosm studies showed that balanced algal $(\mathrm{N}: \mathrm{P}=16)$ and bacterial $(\mathrm{N}: \mathrm{P}$ $\leqslant$ 20-24) elemental compositions are required, providing further evidence that bacterial elemental composition plays a key role in determining the nature of the algae-bacteria relationship and the subsequent development of ciliates.

Thus, when bacteria $(\mathrm{N}: \mathrm{P} \leqslant 20-24)$ and algae $(\mathrm{N}: \mathrm{P} \approx 12)$ were $\mathrm{P}$-sufficient (i.e., at thaw), algal $\mathrm{P}$-incorporation rates were higher than bacterial rates after $\mathrm{P}$ addition (Fig. 6). This P-incorporation resulted in a substantial enhancement of algal abundance (Carrillo et al., submitted). P-enriched algae pursuing a net growth strategy may produce and release enough organic material to meet the P-requirements of bacteria, obviating the need to compete for inorganic nutrients (Caron et al., 2000). In this scenario, bacteria would function as a carbon-link to other trophic levels (ciliate development during thaw experiment) (Fig. 6). In contrast, growth of P-deficient algae (mid-summer) after nutrient pulse generates algal "bloom-growth" that limits the release of organic carbon (Villar-Argaiz et al., 2002a), thereby intensifying the mutualism-commensalism relationship and producing a tendency to bacterial $\mathrm{P}$ impoverishment (to see also Caron et al., 2000) that ultimately restricts the development of the microbial loop (Fig. 6).

When bacteria were $\mathrm{P}$-deficient $(\mathrm{N}: \mathrm{P} \geqslant 20$ 24 , late ice- free period), bacterial P-incorporation rates were significantly higher than algal rates (Fig. 6). Bacterial and primary production, were stimulated after the nutrient pulse, and competition for $\mathrm{P}$ was the prevalent relationship between algae and bacteria (Villar-
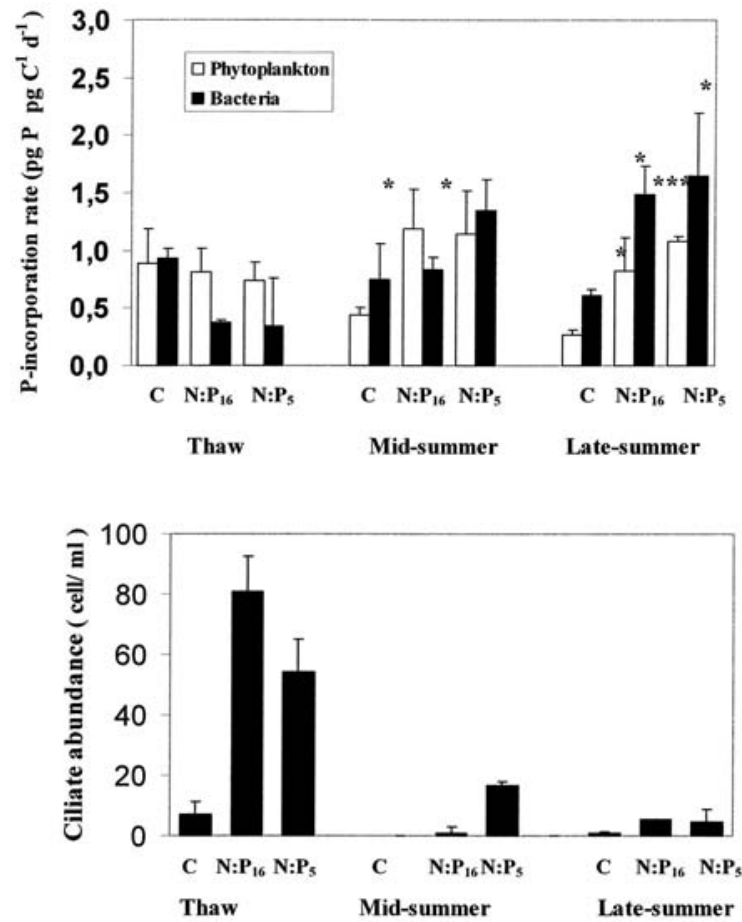

Figure 6. Phytoplankton and bacterial $\mathrm{P}$-incorporation rates in un-enriched (control) and enriched $\left(\mathrm{N}: \mathrm{P}_{16}\right.$ and $\left.\mathrm{N}: \mathrm{P}_{5}\right)$ treatments after short-term incubations $[24 \mathrm{~h}$ in thaw experiment and $48 \mathrm{~h}$ in mid and late ice-free period experiments] (upper panel). Ciliate abundance in un-enriched (control) and enriched $\left(\mathrm{N}: \mathrm{P}_{16}\right.$ and $\left.\mathrm{N}: \mathrm{P}_{5}\right)$ treatments after 15 days incubation period in the thaw, mid and late ice-free period experiments (lower panel). Error bars indicate means \pm SD. Asterisks indicate significantly higher values relative to the controls (onetailed t-test). ${ }^{*} \mathrm{p}<0.05 ; * * \mathrm{p}<0.01 ; * * * \mathrm{p}<0.001$. Tasas de incorporación algal y bacteriana de fósforo en tratamientos no enriquecidos (control) y enriquecidos en fósforo $\left(N: P_{16}\right.$ and $N: P_{5}$ ) [después de 24 horas de incubación en el deshielo y 48 horas en mitad y al final del periodo libre de hielo] (gráfica superior). Abundancia de Ciliados en tratamientos no enriquecido (control) y enriquecido en fósforo ( $N: P_{16}$ and $\left.N: P_{5}\right)$ al final de 15 dias de incubación en el deshielo, mitad y final del periodo libre de hielo (gráfica inferior). Las barras de error son medias $\pm S D$. Los asteriscos indican valores significativamente mayores en relación con el control (t-test). ${ }^{*} p<0.05 ; * * p<0.01 ; * * * p<0.001$.

Argaiz et al., 2002a). In spite of the addition of $P$, bacterial elemental composition did not reach the threshold for balanced growth (Fig. 6). To summarize, the algae-bacteria interaction shifted from mutualism during most of the ice-free period to competition for available $\mathrm{P}$ towards the end of the ice-free period. Therefore, limitation by mineral nutrients can be a transient phe- 
nomenon that lasts for a shorter time than the total turnover of the system (Daufresne \& Loreau, 2001). This interpretation is further sustained by seasonal and inter-annual observations. First, the algal elemental composition is a good predictor of algal growth rate, whereas the bacterial $\mathrm{N}: \mathrm{P}$ ratio is not related to bacterial growth rate (Fig. 7). This lack of relationship indicates that bacteria are limited by an element other than $\mathrm{P}$, despite the strong P-limitation in La Caldera Lake (DIN:TP>40). Second, there is a coupled relation between bacterial and primary production based on a direct dependence on the organic carbon released by algae (see above) (Fig. 3). The prevalence of commensalism over competition contrasts with the clear bacterial P-limitation established for other oligotrophic ecosystems (Rivkin \& Anderson, 1997; Vrede, 1999; Caron et al., 2000; Carlsson \& Caron 2001) and with the Light Nutrient Hypothesis (LNH) (Sterner et al., 1997) on the structure and functioning of aquatic ecosystems. We consider that the main difference with our approach is that the above authors did not include irradiance quality effects within the predictive conceptual framework of the LNH. This is especially important because we have shown that UVR favours algae-bacteria commensalism. Therefore, we can affirm that mutualism-commensalism is more prevalent than competition between algae and bacteria.

However, given that bacteria can tolerate UVR-stress and respond positively to a shift in EOC-availability (basis of the predominantly mutualistic relationship), the question arises as to why they do not reach higher development if $\mathrm{C}$ exceeds bacterial requirements (Carrillo et al., 2002; Medina-Sánchez et al., 2006) and mineral nutrients do not strongly limit their growth (Villar-Argaiz et al., 2002a). Another relevant question is why bacterial production, C-assimilation and use efficiencies show such low or even decreased values (Carrillo et al., 2002; Medina-Sánchez et al., 2004) after the addition of $P$ (Medina-Sánchez et al., 2002; 2006). It appears that other controls are responsible for the scarce abundance and activity of bacteria in La Caldera Lake.
This paradoxical scenario calls for a shift from a simple trophic to a metabolic approach, whereby the "algal" community is divided into strict-autotrophs or mixotrophs.

\section{THE MICROBIAL LOOP DOES NOT DEVELOP. ARE ALGAE ANIMALS OR PLANTS?}

The traditional approach to the energy and matter that flows through an ecosystem involves the classification of organisms into two main trophic groups: osmotrophs/phototrophs (primary producers) and phagotrophs/heterotrophs (consumers). This basic division does not always match the reality of the microbial world because some organisms, such as protista, combine both
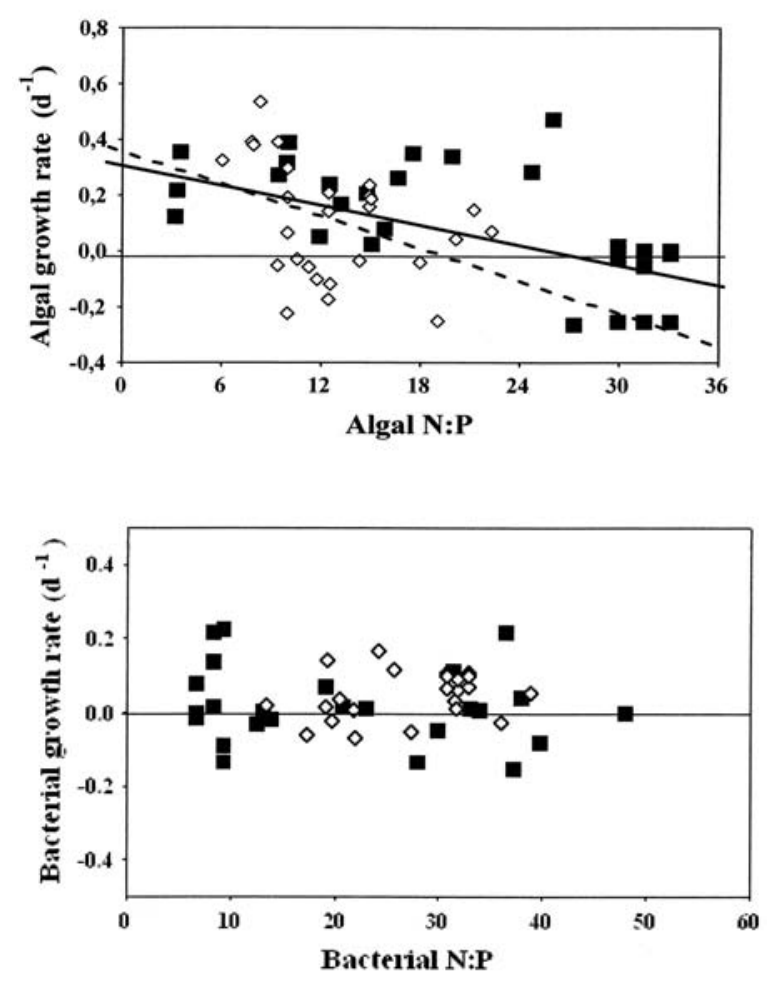

Figure 7. Relationship between algal (upper panel) and bacterial (lower panel) growth rate and elemental composition $(\mathrm{N}: \mathrm{P}$ ratio) of algae and bacteria, respectively, in nutrient-pulse experiments for the mid-and late ice free period experiments. Relación entre la tasa de crecimiento y la composición elemental (razón $N: P$ ) de algas (gráfica superior) y bacterias (grafica inferior), en experimentos de nutrientes pulsados llevados a cabo en la mitad y final del periodo libre de hielo. 
August

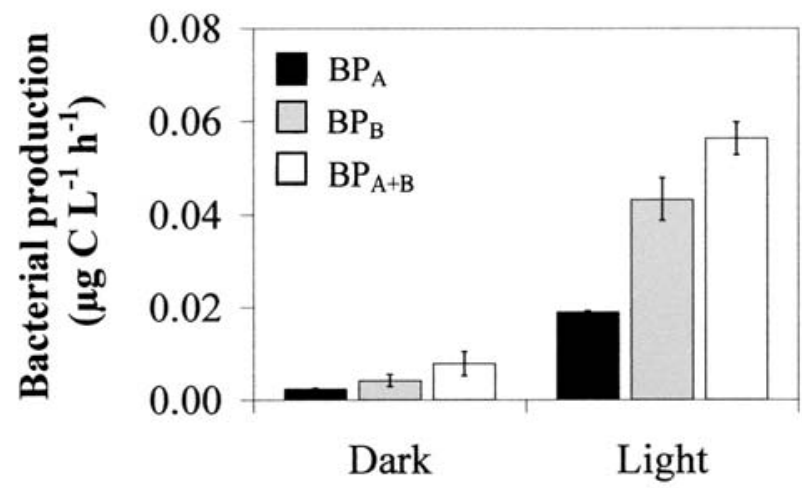

September

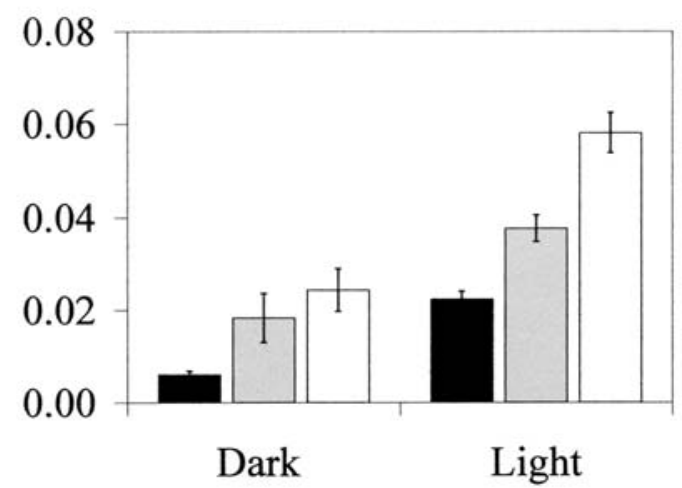

Figure 8. Bacterial production measured as BPA, BPB, and BPA+B in light treatments ('dark' and 'full light') in different moments during the ice-free period. August and September. BPA, Bacterial production incorporated in algal fraction; BPB, bacterial production not incorporated by algae; $\mathrm{BPA}+\mathrm{B}$, bacterial production in both the algal and bacterial fractions. Error bars indicate means \pm SD. Producción bacteriana medida como BPA, BPB y BPA $+B$ en tratamientos de luz (oscuridad y luz completa) en distintos momentos durante el periodo libre de hielo. BPA, Producción bacteriana incorporada en la fracción algal, BPB, Producción bacteriana no incorporada por las algas; BPA+B, Producción bacteriana en las fracciones algales y bacterianas juntas. Las barras de error son medias $\pm S D$.

trophic abilities and are designated mixotrophs (Sanders, 1991; Jones, 1997). By definition, a mixotroph is an organism in which both photosynthesis and phagotrophy are possible (Sanders, 1991). Although mixotrophic metabolism is an energetically more demanding strategy (maintaining both photosynthetic and phagotrophic systems in the same cell) compared with strictly autotrophic or heterotrophic metabolism, mixotrophy has evolved as an adaptive strategy for growth in adverse conditions.

Mixotrophs constitute a functional type usually present in oligotrophic and dystrophic lakes (Salonen \& Jokinen, 1988; Jansson et al., 1996) and at high latitudes (Duthie \& Hart, 1987; Eloranta, 1989, 1995; Lepistö \& Rosenström, 1998), and they are frequently dominant in the phytoplanktonic community of high mountain lakes (Sánchez-Castillo et al., 1989; Carrillo et al., 1990 b, 1991 a, b, 1995; De Hoyos et al., 1998; Straskrabová et al.,1999) and in marine and freshwater ecosystems (Raven, 1997; Sanders et al., 2000; Sherr \& Sherr, 2002).

The dual nature of mixotrophic (autotrophic and heterotrophic) metabolism offers an advantage in ecosystems where light or mineral nutrients are scarce, since the phagotrophic ability enables supplementation of autotrophic growth with the extra C and nutrient contents of prey, e.g., picoplankton (Rothhaupt, 1996 a, b; Raven, 1997). In this way, mixotrophs can constitute a key functional type for the structure of the community and the flow of energy through the food web. They not only contribute to the input of autochthonous $\mathrm{C}$ into the ecosystem but also, by their interaction with picoplankton, constitute a mechanism for the transfer of nutrients and energy towards upper trophic levels, such as zooplankton (Thingstad et al., 1996; Sherr \& Sherr, 2002). On the other hand, it was recently shown that mixotrophy is an adaptive strategy both to deficient environmental conditions and also to excess-induced stress conditions. Thus, MedinaSánchez et al., (2004) found higher bacterial consumption rates by mixotrophs exposed to stressing-sunlight (UVB+UVA+PAR) (Fig. 8), suggesting that bacterivory by mixotrophs allows them to acquire organic carbon and mineral nutrient contents from their prey under inhibitory light conditions (+UVR) for $\mathrm{C}$ fixation (Carrillo et al., 2002) and acquisition of dissolved nutrients (Hessen et al., 1995; Döhler, 1997). 
With this background, we propose that mixotrophy is an adaptive strategy of "algae" to stress by ultraviolet radiation (Medina-Sánchez et al., 2004). Mixotrophy implies a strong predatory control on bacteria, especially on the most active bacteria (Sherr \& Sherr, 2002).

Since algae act both as predators of, and $\mathrm{C}$ suppliers bacteria (dual control), we estimated the relative importance of Predation vs. Resource control by defining a new variable. This variable, designated "algal control", is the ratio between the potential mixotrophic consumption of bacterial production and the photosynthetic $\mathrm{C}$ supplied (i.e. $\mathrm{PMC}_{\mathrm{BP}}$ :EOC, Medina-Sánchez et al., 2004). Figure 9 shows the strong inverse relationship between bacterial production and "algal control" when the algal community is dominated by mixotrophs. Therefore, predation by mixotrophs accounts for the scarcity of bacteria $\left(10^{5}\right.$ cell $/ \mathrm{ml}$, lowest end of the values recorded for oligotrophic ecosystems; Cotner \& Biddanda, 2002) and the low carbon use efficiency by bacteria.

Hence, a complex regulation is established between algae and bacteria, namely "neither

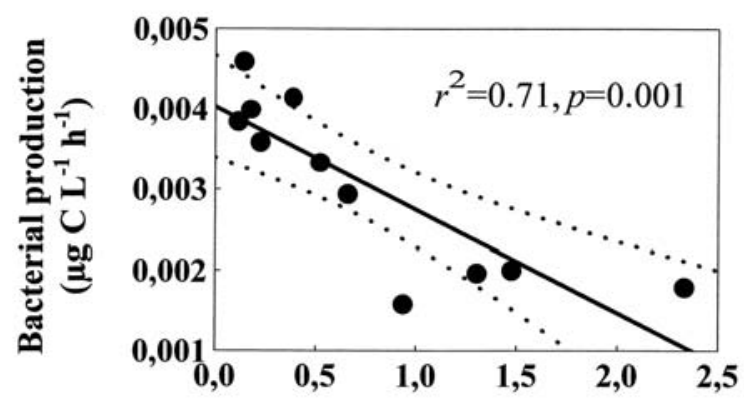

Algal control (PMC ${ }_{\mathrm{BP}}$ :EOC)

Figure 9. Intraannual relationship between bacterial production and 'algal control' measured as the ratio between potential mixotrophic consumption of bacterial $\mathrm{C}$ and photosynthetic C supplied by algae (i.e. PMCbp:EOC). Dashed lines indicate $95 \%$ confidence intervals around the fitted regression line (solid line). Variación estacional en la relación entre la producción bacteriana y el 'control algal' medido como la razón entre consumo de carbono bacteriano por potenciales mixótrofos y el carbono fotosintético aportados por las algas (i.e. PMCbp: EOC). Lineas discontinuas indican el intervalo de confianza del $95 \%$ en relación con la línea de ajuste por regresión (linea continua). with nor without you" (Medina-Sánchez et al., 2004). Bacteria are preyed upon by algae ("with you I die") and simultaneously depend on the organic carbon released by the algae ("without you I cannot live") (Carrillo et al., 2002; Medina-Sánchez et al., 2002, 2004). According to Thingstad et al. (1996), mixotrophs can take advantage in a situation where phytoplankton contribute the organic substrate that bacteria demand, while bacteria can favourably compete with algae for mineral nutrients (Currie \& Kalff, 1984; Cotner \& WetzeL, 1992) and finally, mixotrophs consume these enriched bacteria. Thus, when sunlight is intense and mineral nutrients are scarce, mixotrophic algae are able to grow because they can feed bacteria with "cheap" organic carbon and consume the "expensive" mineral nutrients packaged in the bacteria (sensu Thingstad et al., 1996).

This scenario is consistent with (i) the ability of algae to regulate photosynthetic $\mathrm{C}$ release depending on their elemental composition (Villar-Argaiz et al., 2002a); (ii) the ability of bacteria to grow under high full-sunlight intensities (Carrillo et al., 2002, Medina-Sánchez et al., 2002); and (iii) the decrease in bacterial production in the presence of algae after a nutrient pulse (Medina-Sánchez, 2002, 2006). Furthermore, mixotrophs can retain or release the $\mathrm{P}$ contained in bacteria depending on their predominant nutrition mode (autotrophic vs. phagotrophic) and nutrient requirements (Rothhaupt, 1997).

These abilities can constitute mechanisms that modulate the competition with bacteria for mineral nutrients, suggesting a higher complexity of the algae-bacteria interaction where algae exert the main control. Knowledge of this complex algae-bacteria interaction further advances the understanding of the planktonic structure and energy flow in this kind of aquatic ecosystem:

1) Thus, mixotrophs can overcome the harmful effects of UV radiation and displace: (i) strict autotrophs, less competitive at low concentrations of dissolved mineral nutrients (Rothhaupt, 1996a; Christaki et al., 1999), (ii) picoplankton autotrophs, better adapted to the uptake of dissolved nutrient at low con- 
centrations but more sensitive to the inhibitory effect of UVR (Callieri et al., 2001), and (iii) heterotrophic nanoflagellates (HNF), which depend on a higher minimum threshold of bacterial abundance compared with mixotrophs (Havskum \& Riemann, 1996).

2) With respect to the energy flow, mixotrophic bacterivory acts as a "by-pass" for the flow of energy and nutrients towards the grazing chain (Medina-Sánchez et al., 2004). Hence, mixotrophs would occupy the niche of microheterotrophs and produce a weakening of the traditional microbial loop (Medina-Sánchez et al., 2004). Besides, mixotrophic metabolism may improve the efficiency for the transfer of energy towards upper trophic levels, because the number of trophic steps has been reduced due to the by-pass from the heterotrophic microbial chain to the grazing chain (Fig. 10) (Rivkin \& Anderson, 1997; Medina-Sánchez et al., 2004). Considering all of the above, mixotrophy may at least in part explain the scarce development of the microbial loop in La Caldera Lake.
Nevertheless, several important questions are raised by the fact that mixotrophy is an advantageous metabolism strategy for a system stressed by UVR and oligotrophy and that P-atmospheric input of Saharan origin are relatively frequent: How do allochthonous nutrient inputs affect mixotrophs? Do P pulses interact with UVR in modulating this metabolism? The addressing of these questions responds to the current demand for research into the interactive effects of multiple factors on the functioning and structure of ecosystems.

\section{THE MICROBIAL LOOP DOES NOT DEVELOP. INTERACTION OF LIGHT AND NUTRIENTS?}

The interaction between UVR and atmospheric nutrient inputs can affect species performance and their relationships in ways that cannot be predicted from single-factor analysis, since the effects of two or more factors are non-additive. The interaction among distinct factors can

\section{High Mountain Lake}

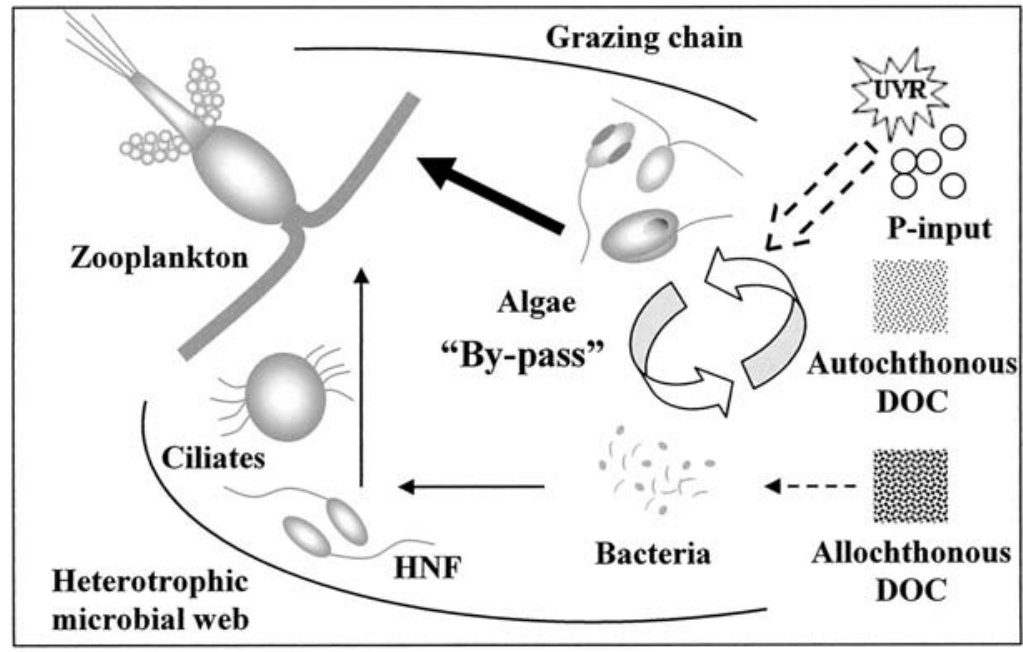

\section{Organic C flux}

Figure 10. Proposed model of carbon flux through microbial food web in oligotrophic clear-water high mountain lakes. The curved arrows indicate reinforcement of the by-pass from bacteria to mixotrophs as a response to the interactive effect between UV radiation and the nutrient-pulses added. Thickness of arrows indicates the relative importance of C flux. Modelo propuesto de flujo de carbono en la red trófica microbiana de lagos oligotróficos claros de alta montaña. Las flechas curvas indican refuerzo del corto circuito desde bacterias a mixótrofos como respuesta al efecto interactivo entre la radiación ultravioleta y los aportes pulsados de nutrientes. El grosor de las flechas indica la importancia relativa del flujo del carbono. 
either shift the sign of the effect of a single-factor (antagonistic effect) or, on the contrary, accentuate this effect (synergetic effect). Therefore, the analysis of multiple factors at different rates and scales is crucial for building a realistic model of the functioning of food webs (Breitburg et al., 1999; Folt et al., 1999; Xenopoulos et al., 2003; Medina-Sánchez et al., 2006). The increasing intensity and frequency of atmospheric material inputs from the Sahara desert to Sierra Nevada is associated with periodic climatic variations (North Atlantic Oscillation, NAO) and movements of the Intertropical Zone Convergence (ITZC). Hence, planktonic communities may be controlled not only by the "harmful" effect of UVR but also by the "stimulatory" effect of allocthonous inorganic nutrients. According to our initial hypothesis, P-pulses would reduce the negative effects that UVR exerts on algae, thereby decreasing the bacterivory rate (associated with mixotrophy). As a consequence, the nutrient pulses would modify the algae-bacteria relationship by shifting it from dual control (with bacterivory) to commensalism. Our investigations on short temporal scales showed that:

1) The elemental composition of algae and bacteria plays a key role in the ecological and biological response to light quality variation and nutrient availability. UVR x P interactions have an antagonistic effect on primary production, C-release by autotrophs, and bacterial production on both communities in un-enriched conditions. This antagonistic effect implies the attenuation or elimination of UVR effects.

2) The interactive effect between solar radiation and atmospheric nutrient inputs on the algaebacteria link reinforces the dual control that algae exert on bacteria, i.e., it increases both the carbon released by algae and the mixotrophic predation on bacteria (MedinaSánchez et al., 2006). The by-pass is therefore enhanced, with consequences for the development of the microbial loop.

Finally, our results have implications at the ecosystem level. Thus, the attenuation of the harmful effects of UVR by P-inputs may smooth UVR stress, which is relevant in a scenario of climatic change with increased UVB fluxes. This buffering effect would be more accentuated in clear-water ecosystems, where the main nutrient inputs have an atmospheric origin, such as in the tropical Atlantic Ocean (Prospero \& Lamb, 2003, see also NOAA htpp://toms.gsfc.nasa.gov/aerosol). In the context of carbon flux, this buffering effect of harmful UVR at the base of both aquatic trophic webs (grazing chain and microbial loop) would favor the diversion of a higher proportion of released carbon flux through biotic webs, trapping carbon that would otherwise be susceptible to photolysis and be lost to the atmosphere.

In spite of the light thrown by this study on the processes that regulate the pelagic community of clear-water high mountain lakes, many areas remain in the shadows and new questions have arisen, briefly summarized as follows:

1. Do the results obtained over short time scales apply to long-term scales (days, weeks or months)?

2. How do UVR $x$ nutrient interactive effects propagate along the grazing chain?

3. How universal are the patterns established for high mountain lakes with high UVR doses? Can structural tendencies established across trophic gradients be extrapolated to high-UVRflux oligotrophic ecosystems?

\section{ACKNOWLEDGMENTS}

We sincerely acknowledge L. Cruz-Pizarro, R. Morales-Baquero, P. Sánchez-Castillo and I. Reche for their contribution to the database. We thank M. J. Villalba assistance in the field. We are indebted to the staff of the Radiopharmacy Department of Granada University for contributing their laboratory and experience. This study was supported by Acidification of Mountain Lakes: Palaeolimnology and Ecology (A1:PE2 EC-ENVIROMENT) Project, Contract Number EV5V-CT92-0205; MOLAR: Measuring and modelling the dynamic response of remote mountain lake ecosystems to environmental change; a programme of mountain lake 
research, Project EC Contract Number ENV4 CT95-0007); the Spanish Ministry Science and Technology Project AMB 0996 (to P.C.), Project REN2001-2840 (to PC). Red UVIFAN: Project FEDER 1FD97-0824, and the Spanish Ministry of Environment RPN25/2003 (to PC).

\section{REFERENCES}

AOTA, Y. \& H. NAKAJIMA. 2001. Mutualistic relationships between phytoplankton and bacteria caused by carbon excretion from phytoplankton. Ecol. Res., 16: 289-299.

AZAM, F., T. FENCHEL, J. G. FIELD, J. S. GRAY, L. A. MEYER-REIL, \& F. THINGSTAD. 1983. The ecological role of water column microbes in the sea. Mar. Ecol. Prog. Ser., 10: 257-263

BERMAN-FRANK, I. \& Z. DUBINSKY. 1999. Balanced growth in aquatic plants: Myth or reality? Bioscience, 49: 29-37.

BIDDANDA, B., M. OGDAHL, \& J. COTNER. 2001. Dominance of bacterial metabolism in oligotrophic relative to eutrophic waters. Limnol. Oceanogr., 46: 730-739.

BREITBURG, D. L., J. G. SANDERS, C. C. GILMOUR, C. A. HATFIELD, R. W. OSMAN, G. F. RIEDEL, S. B. SEITZINGER, \& K. G. SELLNER. 1999. Variability in response to nutrients and trace elements, and transmission of stressor effects through an estuarine food web. Limnol. Oceanogr., 44: 837-863.

CALLIERI, C., G. MORABITO, Y. HUOT, P. J. NEALE, \& E. LITCHMAN. 2001. Photosynthetic response of pico- and nanoplanktonic algae to UVB, UVA and PAR in a high mountain lake. Aquat. Sci., 63: 286-293

CARLSSON, P. \& D. A. CARON. 2001. Seasonal variation of phosphorus limitation of bacterial growth in a small lake. Limnol. Oceanogr., 46: 108-120.

CARON, D. A., E. L. LIM, R. W. SANDERS, M. R. DENNETT, \& U. G. BERNINGER. 2000. Response of bacterioplankton and phytoplankton to organic carbon and inorganic nutrient additions in contrasting oceanic ecosystems. Aquat. Microb. Ecol., 22: 175-184.

CARRILLO, P., L. CRUZ-PIZARRO, \& R. MORALES-BAQUERO. 1990 a. Effects of unpredictable atmospheric allochthonous inputs on the light climate of an oligotrophic lake. Verh. Int. Ver. Limnol., 24: 97-105.
CARRILLO, P., L. CRUZ-PIZARRO, \& P. SÁNCHEZ-CASTILLO.1990b. Analysis of phytoplankton-zooplankton relationships in an oligotrophic lake under natural and manipulated conditions. Hydrobiologia, 200/201: 49-58.

CARRILlO, P., P. SÁNCHEZ-CASTILLO, \& L. CRUZ-PIZARRO. 1991a. Aportación al conocimiento del ciclo biológico de Chromulina nevadensis. Acta Botánica Malacitana: 16 (1): 1-7.

CARRILLO, P., P. SÁNCHEZ-CASTILLO, \& L. CRUZ-PIZARRO. 1991b. Coincident zooplankton and phytoplankton diel migration in an oligotrophic mountain lake (La Caldera, Sierra Nevada, Spain). Arch. Hydrobiol., 122 (1): 57-67.

CARRILLO, P., I. RECHE, P. SÁNCHEZ-CASTILLO, \& L. CRUZ-PIZARRO. 1995. Direct and indirect effects of grazing on the phytoplankton seasonal succession in an oligotrophic lake. $J$. Plankton Res., 17: 1363-1379

CARRILLO, P., I. RECHE, \& L. CRUZ-PIZARRO. 1996. Intra-specific stoichiometric variability and the ratio of nitrogen to phosphorus resupplied by zooplankton. Freshw. Biol., 36: 363-374.

CARRILLO, P., J. M. MEDINA-SÁNCHEZ, \& M. VILLAR-ARGAIZ. 2002. The interaction of phytoplankton and bacteria in a high mountain lake: importance of the spectral composition of solar radiation. Limnol. Oceanogr., 47: 12941306.

CHRISTAKI, U., F. VAN WAMBEKE, \& J. R. DOLAN. 1999. Nanoflagellates (mixotrophs, heterotrophs and autotrophs) in the oligotrophic eastern Mediterranean: standing stocks, bacterivory and relationships with bacterial production. Mar. Ecol. Prog. Ser., 181: 297-307.

CHRZANOWSKI, T. H. \& J. P. GROVER. 2001. Effects of mineral nutrients on the growth of bacterio- and phytoplankton in two southern reservoirs. Limnol. Oceanogr., 46: 1319-1330.

CHRZANOWSKI, T. H., M. KYLE, J. J. ELSER, \& R. W. STERNER. 1996. Element ratios and growth dynamics of bacteria in an oligotrophic Canadian Shield lake. Aquat. Microb. Ecol., 11: 119-125.

COLE, J. J., S. FINDLAY, \& M. L. PACE. 1988. Bacterial production in fresh and saltwater ecosystems: a cross-system overview. Mar. Ecol. Prog. Ser., 43: 1-10.

COTNER, J. B. \& R. G. WETZEL. 1992. Uptake of dissolved inorganic and organic phosphorus compounds by phytoplankton and bacterioplankton. Limnol. Oceanogr., 37: 232-243. 
COTNER, B. J. \& B. A. BIDDANDA. 2002. Small players, large role: Microbial influence on biogeochemical processes in pelagic aquatic ecosystems. Ecosystems, 5: 105-121.

CURRIE, D. J. \& J. KALFF. 1984. The relative importance of phytoplankton and bacterioplankton in phosphorus uptake in freshwater. Limnol. Oceanogr., 29: 311-321.

DAUFRESNE, T. \& M. LOREAU. 2001. Ecological stoichiometry, primary producer-decomposer interactions and ecosystem persistence. Ecology, 82: 3069-3082.

DAVIDSON, A.T. \& A. VAN DER HEIJDEN. 2000. Exposure of natural Antarctic marine microbial assemblages to ambient UV radiation: effects on bacterioplankton. Aquat. Microb. Ecol., 21: 257-264.

DE HOYOS, C., J. J. ALDASORO, M. TORO, \& F. A. COMÍN. 1998. Specific composition and ecology of chrysophyte flagellates in Lake Sanabria (NW Spain). Hydrobiologia, 369/370: 287-295

DEL GIORGIO, P. A. \& G. SCARBOROUGH. 1995. Increase in the proportion of metabolically active bacteria along gradients of enrichments in freshwater and marine plankton: implications for estimates of bacterial growth and production rates. J. Plankton Res., 17: 1905-1924.

DÖHLER, G. 1997. Effect of UVB radiation on utilization of inorganic nitrogen by Antarctic microalgae. Photochem. Photobiol., 66: 831-836.

DUARTE, C. M., S. AGUSTÍ, J. M. GASOL, D. VAQUÉ, \& E. VAZQUEZ-DOMÍNGUEZ. 2000. Effect of nutrient supply on the biomass structure of planktonic communities. An experimental test on a Mediterranean coastal community. Mar. Ecol. Prog. Ser., 206: 87-95.

DUTHIE, H.C. \& C. J. HART. 1987. The phytoplankton of the subarctic Canadian Great Lakes. Arch. Hydrobiol. Beih., 25: 1-9.

ELORANTA, P. 1989. Scaled chrysophytes (Chrysophyceae and Synurophyceae) from national park lakes in southern and central Finland. Nord. J. Bot., 8: 671-681.

ELORANTA, P. 1995. Phytoplankton of the national park lakes in central and southern Finland. Ann. Bot. Fenn., 32: 193-209.

ELSER, J. J., D. DOBBERFUHL, N. A. MACKAY, \& J. H. SCHAMPEL. 1996. Organism size, life history, and N:P stoichiometry: Toward a unified view of cellular and ecosystem processes. Bioscience 46: 674-684.

ELSER, J. J. \& D. O. HESSEN. 2005. Biosimplicity via stoichiometry: the evolution of food-web structure and processes. In: Aquatic Food Webs: an Ecosystem Approach. Belgrano, Scharler, Dunne and Ulanowicz (eds.): 7-18. Oxford. Univ. Press. 255 pp.

FOLT, C. L., C. Y. CHEN, M. V. MOORE, \& J. BURNAFORD. 1999. Synergism and antagonism among multiple stressors. Limnol. Oceanogr., 44: 864-877.

GASOL, J. M., P. A. DEL GIORGIO, \& C. M. DUARTE. 1997. Biomass distribution in marine planktonic communities. Limnol. Oceanogr., 42: 1353-1363.

HAVSKUM, H., \& B. RIEMANN. 1996. Ecological importance of bacterivorous, pigmented flagellates (mixotrophs) in the Bay of Aarhus, Denmark. Mar. Ecol. Prog. Ser., 137: 251-263.

HESSEN, D. O., E. VAN DONK, \& T. ANDERSEN. 1995. Growth responses, P-uptake and loss of flagella in Chlamydomonas reinhardtii exposed to UV-B. J. Plankton Res., 17: 17-27.

HOLT, R. D. 1995. Linking species and ecosystems: where's Darwin? In: Linking Species \& Ecosystems. C.G. Jones \& J.H. Lawton (eds): 273279. Chapman \& Hall, New York. 386 pp.

JOINT, I., P. HENRIKSEN, G. A. FONNES, D. BOURNE, T. F. THINGSTAD, \& B. RIEMANN. 2002. Competition for inorganic nutrients between phytoplankton and bacterioplankton in nutrient manipulated mesocosms. Aquat. Microb. Ecol., 29: 145-159.

JONES, H. L. J. 1997. A classification of mixotrophic protists based on their behavior. Freshwat. Biol., 37: 35-43.

KAISER, E. \& G. J. HERNDL. 1997. Rapid recovery of marine bacterioplankton activity after inhibition by UV radiation in coastal waters. Appl. Environ. Microbiol., 63: 4026-4031.

KIM, S. T. \& A. SANCAR. 1993. Photochemistry, photophysics, and mechanisms of pyrimidine dimer repair by DNA photolyase. Photochem. Photobiol., 57: 895-904.

LE, J., J. D. WEHR, \& L. CAMPBELL. 1994. Uncoupling of bacterioplankton and phytoplankton production in fresh waters is affected by inorganic nutrient limitation. Appl. Environ. Microbiol., 60: 2086-2093.

LEPISTÖ, L. \& U. ROSENSTRÖM.1998. The most typical phytoplankton taxa in four types of boreal lakes. Hydrobiologia, 369/370: 89-97.

LINDEMAN, R. L. 1942. The trophic dynamic aspect of ecology. Ecology, 23(4): 399-418

LITCHMAN, E., P. J. NEALE, \& A. T. BANASZAK. 2002. Increased sensitivity to ultraviolet radiation 
in nitrogen-limited dinoflagellates: Photoprotection and repair. Limnol. Oceanogr., 47: 86-94.

MARGALEF, R. 1992. Ecología. $5^{\text {a }}$ ed. Barcelona: Planeta. $255 \mathrm{pp}$.

MEDINA-SÁNCHEZ, J. M., M. VILLAR-ARGAIZ, P. SÁNCHEZ-CASTILLO, L. CRUZ-PIZARRO, \& P. CARRILLO. 1999. Structure changes in a planktonic food web: biotic and abiotic controls. J. Limnol., 58: 213-222.

MEDINA-SÁNCHEZ, J. M., M. VILLAR-ARGAIZ, \& P. CARRILLO. 2002. Modulation of the bacterial response to spectral solar radiation by algae and limiting nutrients. Freshwat. Biol., 47: 2191-2204.

MEDINA-SÁNCHEZ, J. M., M. VILLAR-ARGAIZ, \& P. CARRILLO. 2004. Neither with nor without you: a complex algal control on bacterioplankton. Limnol. Oceanogr., 49: 1722-1733.

MEDINA-SÁNCHEZ, J. M., M. VILLAR-ARGAIZ, \& P. CARRILLO. 2006. Solar radiation-nutrient interaction enhances the resource and predation algal control on bacterioplankton: A short-term experimental study. Limnol. Oceanogr., 51: 913-924.

MICHENER W. K., T. J. BAERWALD, P. FIRTH, M. A. PALMER, J. L. ROSENBERGE, E. A. SANDLIN, \& H. ZIMMERMAN. 2001. Defining and unraveling biocomplexity. BioScience, 51: 10181023.

MORALES-BAQUERO, R., P. CARRILLO, I. RECHE, \& P. SÁNCHEZ-CASTILLO. 1999. The nitrogen: phosphorus relationship in high mountain lakes: effects of the size of catchment basins. Can J. Aquat Sci., 56: 1809-1817.

OBERNOSTERER, I. \& G. J. HERNDL. 1997. Phytoplankton extracellular release and bacterial growth: dependence on the inorganic N:P ratio. Mar. Ecol Prog. Ser., 116: 247-257.

PACE, M. L. \& J. J. COLE. 1994. Primary and bacterial production in lakes: are they coupled over depth? J. Plankton Res., 16: 661-672.

PIMM, S. L., J. H. LAWTON \& J. E. COHEN. 1991. Food web patterns and their consequences. Nature, 350: 669-674.

POMEROY, L. R. 1974 The ocean's food web: a changing paradigm BioScience, 24: 499-504.

PULIDO-VILLENA, E. 2004. El papel de la deposición atmosférica en la biogeoquímica de las lagunas de Alta Montaña (Sierra Nevada, España). Tesis Doctoral, Universidad de Granada. 296 pp.

RAVEN, J. A. 1997. Phagotrophy in phototrophs. Limnol. Oceanogr., 42: 198-205

RECHE, I., P CARRILLO, \& L. CRUZ-PIZARRO. 1997. Influence of metazooplankton on interac- tions of bacteria and phytoplankton in an oligotrophic lake. J. Plankton Res., 19: 631-646.

RECHE, I., A. PUGNETTI, L. CRUZ-PIZARRO, \& P CARRILLO. 1996. Relationship between bacteria and phytoplankton in a high-mountain lake: Importance of the organic carbon released by pelagic algae for bacterioplankton. Arch. Hydrobiol., 48: 31-38.

RECHE, I., E. PULIDO-VILLENA, J. M. CONDEPORCUNA, \& P. CARRILLO. 2001. Photoreactivity of dissolved organic matter from high mountain lakes of Sierra Nevada (Spain). Arct. Antarct. Alp. Res., 33: 426-434.

RIVKIN, R. B. \& M. R. ANDERSON. 1997. Inorganic nutrient limitation of oceanic bacterioplankton. Limnol. Oceanogr., 42: 730-740.

RODRIGUEZ, J. 1999. Ecología. Madrid: Pirámide. $411 \mathrm{pp}$.

ROTHHAUPT, K. O. 1996a Utilization of substitutable carbon and phosphorus sources by the mixotrophic chrysofite Ochromonas sp. Ecology, 77: 706-715.

ROTHHAUPT, K. O. 1996b. Laboratory experiments with a mixotrophic chrysophyte and obligately phagotrophic and phototrophic competitors. Ecology, 77: 716-724.

ROTHHAUPT, K. O. 1997. Nutrient turnover by freshwater bacterivorous flagellates:differences between a heterotrophic and a mixotrophic chrysophyte. Aquat. Microb. Ecol., 12: 65-70.

SALONEN, K. \& S. JOKINEN.S. 1988. Flagellate grazing on bacteria in a small dystrophic lake. Hydrobiologia, 161: 203-209.

SAMUELSSON, K., J. BERGLUND, P. HAECKY, $\&$ A. ANDERSSON. 2002. Structural changes in an aquatic food web caused by inorganic nutrient addition. Aquat. Microb. Ecol., 29: 29-39.

SÁNCHEZ-CASTILLO, P., L. CRUZ-PIZARRO y P. CARRILLO. 1989. Caracterización del fitoplancton de las lagunas de alta montaña de Sierra Nevada (Granada, España) en relación con las características físico-químicas del medio. Limnetica, 5: 37-50.

SANDERS, R. W. 1991 Mixotrophic Protists In Marine And Fresh-Water Ecosystems. J. Protozool., 38: 76-81.

SANDERS, R. W., U. G BERNINGER, E. L. LIM, P. F. KEMP, \& D. A. CARON. 2000. Heterotrophic and mixotrophic nanoplankton predation on picoplankton in the Sargasso Sea and on Georges Bank. Mar. Ecol. Prog. Ser., 192: 103-118.

SHERR, E. B. \& B. F. SHERR. 2002. Significance of predation by protists in aquatic microbial food webs. Anton Leeuw. Int J. G., 81: 293-308. 
STERNER, R. W., J. J. ELSER, E. J. FEE, S. J. GUILDFORD, \& T. H. CHRZANOWSKI. 1997. The light:nutrient ratio in lakes: the balance of energy and materials affects ecosystem structure and process. Am. Nat., 150: 663-684.

STERNER, R. W. \& J. J. ELSER. 2002. Ecological Stoichiometry: The biology of elements from molecules to the biosphere. Princeton University Press. USA. 439 pp.

STRASKRABOVÁ, V., C. CALLIERI, \& J. FOTT. 1999. Pelagic food webs in mountain lakes MOuntain LAkes Research Program. J. Limnol., 58: 77-222.

TARAPCHAK, S. J. \& R. A. MOLL. 1990. Phosphorus sources for phytoplankton and bacteria in Lake Michigan. J. Plankton Res., 12: 743-758.

TEIRA, E., M. J. PAZÓ, P. SERRET, \& E. FERNÁNDEZ. 2001. Dissolved organic carbon production by microbial population in the Atlantic Ocean. Limnol. Oceanogr., 46: 1370-1377.

THINGSTAD, T. F., H. HAVSKUM, K. GARDE, \& B. RIEMANN. 1996. On the strategy of "eating your competitor": a mathematical analysis of algal mixotrophy. Ecology, 77: 2108-2118.

VADSTEIN, O. 2000. Heterotrophic, planktonic bacteria and cycling of phosphorus: Phosphorus requirements, competitive ability and food web interactions. Adv. Microb. Ecol., 16: 115-168.

VAQUÉ, D., H. A. BLOUGH, \& C. M. DUARTE. 1997. Dynamics of ciliate abundance, biomass and community composition in an oligotrophic coastal environment (NW Mediterranean). Aquat. Microb. Ecol., 12: 71-83.

VILLAR-ARGAIZ, M., J. M. MEDINA-SÁNCHEZ, \& P. CARRILLO. 2001. Inter- and intra-annual variability in the phytoplankton community of a high mountain lake: the influence of external (atmospheric) and internal (recycled) sources of P. Freshwat. Biol., 46: 1017-1024.

VILLAR-ARGAIZ, M., J. M. MEDINA-SÁNCHEZ, \& P. CARRILLO. 2002a. Microbial plankton response to contrasting climatic conditions: insights from community structure, productivity and fraction stoichiometry. Aquat. Microb. Ecol., 29: 253-266.

VILLAR-ARGAIZ, M., J. M. MEDINA-SÁNCHEZ, \& P. CARRILLO. 2002b. Interannual changes in the $\mathrm{C}: \mathrm{N}: \mathrm{P}$ ratios of seston and zooplankton of a high mountain lake in Sierra Nevada, Spain. Water Air Soil Poll. Focus, 2: 359-378.

VINCENT, W. F. \& S. ROY. 1993. Solar ultraviolet-B radiation and aquatic primary production: damage, protection, and recovery. Environ. Rev., 1: 1-12.

VREDE, K. 1999. Effects of inorganic nutrients and zooplankton on the growth of heterotrophic bacterioplankton-enclosure experiments in an oligotrophic clear-water lake. Aquat. Microb. Ecol., 18: 133-144.

XENOPOULOS, M. A. \& P. C. Frost. 2003. UV radiation, phosphorus, and their combined effects on the taxonomic composition of phytoplankton in a boreal lake. J. Phycol., 39: 291-302. 